Fight-or-Flight Response: A Study of Bahaa Taher's Sunset Oasis with Reference to Trauma Theory

\author{
By: Dr. Nermin Ahmed Haikal \\ Assistant Professor of English Literature \\ The Department of English Language and Literature \\ Faculty of Women, for Arts, Science and Education \\ Ain Shams University
}




\title{
Fight-or-Flight Response: A Study of Bahaa Taher's Sunset Oasis with Reference to Trauma Theory
}

\begin{abstract}
:
Man's eternal quest from innocence to experience is marked by his ability to face different challenges. Some experiences teach a lesson while others cause severe injury. People's reactions are not the same when it comes to traumatic events. In moments of danger, some people manage to 'fight' for survival while others escape when they face life-threatening incidents. People who fail to 'fight' are helpless in repeated moments of danger. Lenore Terr declares that "psychic trauma occurs when a sudden, unexpected, overwhelming intense emotional blow or a series of blows assaults the person from outside. Traumatic events are external, but they quickly become incorporated into the mind"(8). The aim of this paper is to apply trauma theory to Bahaa Taher's Sunset Oasis which was awarded the International Prize for Arabic Fiction in 2008. Taking place in the remote area of Siwa Oasis, the novel deals with Mahmoud Abd el Zahir, who is sent by the British authorities to Siwa Oasis as District Commissioner as a punishment for his participation in the outbreak with Urabi at the end of the 19th century. Mahmoud suffers serious blows as a result of the British bombing of Alexandria, Urabi's defeat, the king's betrayal and his friend Tal'at's testimony. Nevertheless, Mahmoud's real trauma results from his own testimony during the second investigation in which he fails to ' $f i g h t$ ' for his country. Focusing on the impact of the journey through the desert and life in Siwa Oasis, this study investigates the narrative techniques employed by the author to recall devastating moments of helplessness which drag Mahmoud into severe injuries until his final dramatic end.
\end{abstract}

Keywords: Trauma - Fight or flight response - PTSD - Sunset Oasis 


\section{Fight-or-Flight Response: A Study of Bahaa Taher's Sunset Oasis with Reference to Trauma Theory}

\section{Introduction:}

In his article titled "Trauma and Literary Theory", James Berger asks "why, at this moment, trauma should attract such attention and become a pivotal subject connecting many disciplines"(569). Referring to the history of this century, Berger rightly alters his question to, "how trauma could not be a primary concern"(570). While Anne Whitehead in the introduction of Trauma Fiction declares that "[t]he rise of trauma theory has provided novelists with new ways of conceptualising trauma and has shifted attention away from the question of what is remembered of the past to how and why it is remembered. This raises, in turn, the related issues of politics, ethics and aesthetics"(3). Trauma theory helps in understanding the huge impact of catastrophic and overwhelming experiences on people. Elisa Marder declares that over the last years, "the emergence of groundbreaking new work on trauma in literature and critical theory has made profound impact both within and beyond the field of literature"(1). She points out that, "because traumatic events often happen due to social forces as well as in the social world, trauma has an inherently political, historical, and ethical dimension"(1).

The aim of this paper is to apply trauma theory to Bahaa Taher's Sunset Oasis (originally published in 2007 as Wahat al-Ghurub). In 2008, the novel was awarded the International Prize for Arabic Fiction "the socalled 'Arabic Booker"'(Qualey 1). The novel explores "the story of the fictionalized Mahmoud Abd el Zahir, who is sent to Siwa as District Commissioner at the end of the 19th century. Mahmoud must bring Siwa under control and collect their back taxes - a thankless task, and one for which the previous District Commissioner was killed"(1). Mahmoud "is accompanied by his Irish wife, Catherine, who is thrilled at the chance to come nearer to little-seen antiquities"(1). Mahmoud believes that the posting is a punishment for his participation in the outbreak with Urabi. Mahmoud suffers serious blows as a result of the British bombing, Urabi's defeat, the king's betrayal and his friend Tal'at's testimony. Nevertheless, Mahmoud's real trauma results from his own testimony during the same investigation in which he fails to fight for his country. Focusing on the impact of the journey through the desert and life in Siwa Oasis, the current study aims to investigate the narrative techniques employed by the author to recall devastating moments of helplessness which drag Mahmoud into severe injuries until his final dramatic end. 


\section{Surviving Traumatic Experiences:}

The study of trauma ranges from domestic and personal trauma to cultural and war trauma. Encompassing a vast range of experiences, the study of trauma helps in understanding the profound psychological struggles and challenges that people face in their quest from innocence to experience. Though some experiences teach lessons, traumatic experiences may cause severe injuries. People's reactions are not the same when it comes to traumatic events. In moments of danger, some people manage to fight for survival while others escape when they face life-threatening incidents. People who fail to fight are helpless in repeated moments of danger. Lenore Terr declares that "psychic trauma occurs when a sudden, unexpected, overwhelming intense emotional blow or a series of blows assaults the person from outside. Traumatic events are external, but they quickly become incorporated into the mind"'(Terr 8).

In her study "Trauma Theory Abbreviated," Sandra L. Bloom states that in order to "understand what trauma does we have to understand what it is"(1). Bloom considers the fight-or-flight response the main reason for trauma. She explains the real nature of the fight-or flight response saying,

we are biologically equipped to protect ourselves from harm as best we can. The basic internal protective mechanism is called the fight-or-flight reaction. Whenever we perceive that we are in danger our bodies make a massive response that affects all of our organ systems. This change in every area of basic function is so dramatic that in many ways, we are not the same people when we are terrified as when we are calm. (2)

Bloom explains that some people manage to fight in moments of danger while others fail to fight and escape when they face lifethreatening experiences. People who fail to fight are helpless in repeated moments of danger. Bloom explains the situation of 'learned helplessness' saying,

If a person is able to master the situation of danger by successfully running away, winning the fight or getting help, the risk of long-term physical changes are lessened. But in many situations considered to be traumatic, the victim is helpless and it is this helplessness that is such a problem for human beings. As a species, we cannot tolerate helplessness - it goes against our instinct for survival. (3) 
Furthermore, Bloom points out that "it is not the trauma itself that does the damage. It is how the individual's mind and body reacts in its own unique way to the traumatic experience in combination with the unique response of the individual's social group"(1). Hence, a traumatic experience "impacts the entire person - the way we think, the way we learn, the way we remember things, the way we feel about ourselves, the way we feel about other people, and the way we make sense of the world are all profoundly altered by traumatic experience"(1).

In Unclaimed Experience: Trauma, Narrative, and History (1996), Cathy Caruth describes trauma as

the response to an unexpected or overwhelming violent event or events that are not fully grasped as they occur, but return later in repeated flashbacks, nightmares, and other repetitive phenomena. Traumatic experience, beyond the psychological dimension of suffering it involves, suggests a certain paradox: that the most direct seeing of a violent event may occur as an absolute inability to know it; that immediacy, paradoxically, may take the form of belatedness. (91-92)

James Berger reflects upon Cathy Caruth's path-breaking work saying that Caruth "is concerned principally with questions of reference and representation: how trauma becomes text, or, as she puts it in her introduction, how wound becomes voice"(577). Caruth determines that "[t]he story of trauma, then, as the narrative of belated experience, far from telling of an escape from reality - the escape from death, or from its referential force - rather attests to its endless impact on life"(Unclaimed Experience 7). She argues that "[t]he crisis at the core of many traumatic narratives ... often emerges, indeed, as an urgent question: Is the trauma the encounter with death, or the ongoing experience of having survived it?"(7). Hence, Caruth depicts the nature of trauma as "the oscillation between a crisis of death and the correlative crisis of life: between the story of the unbearable nature of an event and the story of the unbearable nature of its survival"(7).

While Judith Herman depicts psychological trauma as "an affiliation of the powerless. At the moment of trauma, the victim is rendered helpless by overwhelming force. When the force is that of nature, we speak of disasters. When the force is that of other human beings, we speak of atrocities. Traumatic events overwhelm the ordinary systems of care that give people a sense of control, connection, and meaning"(24). Herman considers traumatic events "extraordinary, not 
because they occur rarely, but rather because they overwhelm the ordinary human adaptations to life"(24). Herman further explains her view saying "[u]nlike commonplace misfortunes, traumatic events generally involve threats to life or bodily integrity, or a close personal encounter with violence and death. They confront human beings with the extremities of helplessness and terror, and evoke the responses of catastrophe"( 24).

Herman, like Caruth and Bloom, considers the impact of a lifethreatening event on both victims and witnesses as far more traumatic than the event itself. Though the victim is totally helpless at the traumatic moment, his injury after the moment is past cannot be tolerated. The traumatic event confronts the victim with his extreme helplessness and renders the survivor or witness in another state of helplessness. Herman declares that "[w]itnesses as well as victims are subject to the dialectic of trauma"(1).

In Trauma and the Memory of Politics, Jenny Edkins states that the traumatic event "has to be more than just a situation of utter powerlessness. It has to involve a betrayal of trust as well"(4). Edkins further explains her concept saying, "trauma takes place when the very powers that we are convinced will protect us and give us security become our tormentors: when the community of which we considered ourselves members turns against us or when our family is no longer a source of refuge but a site of danger"(4). Edkins agrees with Herman in considering that "[w]itnessing violence done to others and surviving can seem to be as traumatic as suffering brutality oneself'(4).

James Berger points out that Cathy Caruth's introduction "The Wound and the Voice", "opens new ground" in dealing with "the relation between pain and language, in its narrative, historical, and ethical dimensions"(577). Berger depicts Caruth's argument that "trauma as it first occurs is incomprehensible. It is only later, after a period of latency, that it can be placed in a narrative"(577). Caruth points out the peculiar fact that "the pathology cannot be defined . . . by the event itself - which may or may not be catastrophic, and may not traumatize everyone equally"(Caruth, Trauma: Explorations in Memory 4).

Bloom's analysis of what she terms "engraving" of trauma in various survivor groups sheds light on Cathy Caruth's concept of belatedness.

Problems may arise later because the memory of the events that occurred under severe stress are not put into words and are not remembered in the normal way we remember other 
things. Instead, the memories remain "frozen in time" in the form of images, body sensations like smells, touch, tastes, and even pain, and strong emotions. (Bloom 6)

She further explains that those un-verbalized 'images' or 'body sensations' are only re-experienced in the form of "flashback" with a new stimulus. Bloom defines flashback as

a sudden intrusive re-experiencing of a fragment of one of those traumatic, unverbalized memories. During a flashback, people become overwhelmed with the same emotions that they felt at the time of the trauma. Flashbacks are likely to occur when people are upset, stressed, frightened, or aroused or when triggered by any association to the traumatic event. Their minds can become flooded with the images, emotions, and physical sensations associated with the trauma and once again. (6)

Hence, a repeated flashback is one of the key devices that represent trauma in literary narratives. In the early stages of post-traumatic stress disorder, known as hyperarousal and intrusion, the repetition of flashbacks and the recurrence of nightmares reveal the damaging impact of trauma on characters.

This can be applied to Bahaa Taher's Sunset Oasis which was awarded the International Prize for Arabic Fiction in 2008. In Sunset Oasis the author's successful choice of the technique of shifting narrative, "several first-person narrators" allows him to communicate precisely to the reader the different impact of various events on individual characters (Aspden 1). This technique is further enhanced by means of a flow of interior monologues for each character conveying to the reader the character's concealed thoughts and deep feelings and emotions. The peculiar structure of the book being divided into chapters entitled with the character's name and narrated from this character's perspective, allows the author to delve deep and psychologically communicate each character's feelings and meditations towards the different experiences they have passed through. Karen Luscombe describes Sunset Oasis as "an ambitious philosophical query into the natures of history, betrayal, passion and fiction - massive themes each, which Taher filters through an estranging prism of glancing monologues"(Luscombe 4). While Rachel Aspden points out that Sunset Oasis "offers a welcome glimpse of a troubled period of Egypt's history largely forgotten by its British colonisers and an absorbing portrait of a would-be good man destroyed by bad times"(Aspden 3). Studied as a historical novel, Sunset Oasis has 
been compared to other novels in "Fictions of Revolution: Empire and Nation in Lawrence Durell, Naguib Mahfouz, John Wilcox, and Bahaa Taher" (2014). Sunset Oasis has also been examined from a postcolonial perspective in "Identity Quest: When East Meets West in Bahaa Taher's Sunset Oasis, A Post-Colonial Reading” (2017).

The current study, however, aims to apply trauma theory on Sunset Oasis. The book is skillfully woven in such a way that characters revolve around different traumatic experiences. Nevertheless, their reactions to similar traumatic experiences are not the same. Instead of a background introduction of major and minor characters, Taher narrates background of the traumatic experience that the character suffered and the character's helplessness in facing its impact through one of the devices of 'flashback', 'recurring nightmares' or 'repetition'. The reader, unlike the rest of the characters, gradually understands characters' attitudes and the reasons behind their switching mood, impatience and sometimes static rejection of change.

Bahaa Taher's book seems to imply the fact that traumatic experiences are not exceptional for wretched people; he suggests that trauma prevails. Taher depicts people's failure to fight at certain moments in their life. Their flight or escape reflects their helplessness and weakness. He depicts how their escape and defeat cause them severe injury for a long duration. Some manage to recover injury while others fail. Those who are unable to recover suffer traumatic cardinal phases known as post-traumatic stress disorder (shortened as PTSD) and unfortunately some of them end their own lives. This study will focus on the protagonist's trauma in Sunset Oasis. Lindesay Irvine states that Sunset Oasis "follows one man's journey" depicting that the book has been described by the prize's website as following "a journey that crystallises the existential crisis of a defeated man"(Irvine 1). Mahmoud's failure to fight at critical moments in his life is depicted through a number of flashbacks when triggered by similar life-threatening experiences. Mahmoud's series of flashbacks as well as recurring dreams reveal different cardinal stages of PTSD until his final dramatic end.

In Trauma: Explorations in Memory, Cathy Caruth declares that though "the precise definition of post-traumatic stress disorder is contested"(4), most descriptions generally agree that

there is a response, sometimes delayed, to an overwhelming event or events, which may take the form of repeated, intrusive hallucinations, dreams, thoughts or behaviors stemming from the event, along with numbing that may have begun during or after the experience, and possibly also 
increased arousal to (and avoidance of) stimuli recalling the event.(4)

Judith Herman, divides the symptoms of post-traumatic stress disorder into three main phases; 'hyperarousal', 'intrusion', and 'constriction'. Hyperarousal "reflects the persistent expectation of danger," intrusion "reflects the indelible imprint of the traumatic moment," while constriction "reflects the numbing response of surrender"(Herman 25).

As the book opens, Mahmoud is at the stage of "hyperarousal"; the first cardinal stage of PTSD which reflects what Herman describes as "the persistent expectation of danger"(25). At the end of the $19^{\text {th }}$ century, Mahmoud Abd el Zahir is condemned by the British authorities and is sent to Siwa Oasis as District Commissioner under the guise of a promotion. The transfer order is imposed on Mahmoud as a punishment for his participation in the outbreak with Urabi. Mahmoud's expectation of danger is clearly stated, "[m]y fear of the caravan's safe arrival at its destination is no less than my fear of its getting lost. I know very well I am going to the place where it is my destiny to be killed"(Taher 14). He tries hard but fails to evade this life-threatening journey against which the author uses different characters to warn the protagonist "the brigadier general advised me, as a friend, to abandon the idea of taking my wife: the journey to the oasis was not easy, the posting itself very difficult ... it was his duty to warn me of the danger of the journey. . . . Saeed wasn't trying to scare me"(Taher 13). Nevertheless, Mahmoud travels in a caravan accompanied by his Irish wife who has been described as "brave"(13) and "courageous"(22). The tough journey and the harsh environment of the dry, hollow and empty desert arouse in Mahmoud wretched feelings and remind him of miserable events of his life.

\section{The Impact of the Journey through the Desert on the Protagonist:}

The author clearly depicts the impact of the journey through the desert on Mahmoud who believes that "the desert affects us all differently"(41). Mahmoud meditates, "[t]he desert stretches away before my eyes and there is nothing in it but sand, dunes, rocks, and the mirage that shimmers in the distance. Searing heat by day and biting cold by night'(37). Mahmoud ironically recalls Saeed's description of the desert as 'garden of the spirit'. "His spirit may be, not mine. It moves nothing in me, this yellow 'garden'. Except anger, perhaps"(37). Mahmoud cannot also see what amazes his wife, Catherine, "I steal a glance at Catherine and behold her at the back of her camel, turning her head right and left with an unquenchable amazement in her eyes. Does she too see the 'garden' of Brigadier General Saeed? What is there new to keep catching 
her attention like that?"(40). He later explains to Catherine how the desert affects him, "I have another desert stretching inside me, with nothing in it of the silence of this desert we are crossing - a desert full of voices and people and images. ... sterile like the desert. All of them hark back to a past that is dead, but they pursue me all the time"(41). Mahmoud meditates, "[a]s each day passes on the road, a deeper silence reigns over the caravan. . . . but the silence floods my mind with cries and images that awaken all the past - all who are alive and all who have passed away"(37).

The silence of the desert awakens in Mahmoud morbid memories of death. Mahmoud recalls his mother's death and the injury it has caused him, "I make every effort to forget my mother, but on this trip I cannot"(38). He remembers clear details of the night of her death, "sitting in her large chair" waiting for his return as usual and asking him to bring her a cup of water. Mahmoud thinks "when I opened the door, cup in hand, I saw her head drooping on her chest. . . . she was gone"(38). His inability to grasp her unexpected, quick and peaceful death is clear,

I went two months incapable of taking anything in. I would repeat to all who offered me condolences everything that had occurred between my leaving the room and my returning to it, as though these details concealed some secret or riddle that would explain what had happened. And my legs shook when I walked. I didn't understand and I still can't understand. (38)

Hence, the tough journey through the silent desert moves Mahmoud to the second cardinal stage of 'intrusion' which as Herman depicts "reflects the indelible imprint of the traumatic moment. . . The traumatic moment becomes encoded in an abnormal form of memory, which breaks spontaneously into consciousness, both as flashbacks during waking states and as traumatic nightmares during sleep"(Herman 25-26). Though the desert reminds him of past but sad memories, it is the experience of facing death during the sandstorm that triggers similar past memories that he tries to forget. The author uses the technique of flashback to recount Mahmoud's crisis.

On the ninth night of the journey a terrible sandstorm broke. Mahmoud explains, "total darkness fell upon us and the roaring enveloped us. . . . All that existed was a deluge of sand and stones that came from all directions and piles up on top of us . . I thought to myself that they would bury us for ever"'(Taher 42). The impact of this lifethreatening experience on Mahmoud is severe stimulating distorted 
feelings towards death. "I wished for death with all my heart. . . The thought 'Let it come' flashed into my mind. . . . Let it come quickly! I want the end, as a beautiful relief from a burden I can no longer carry. Let it come!"(42-43). He confesses to Catherine that facing death "wasn't frightening"(43), but he "was incapable of explaining to her how it was the nearness of death which had made it familiar and desirable"(43).

Mahmoud's contradictory feelings towards death refer to his early crisis. "Yes, I fear death, but despite that I was prepared, at one time, to meet it without hesitation. In those days there was meaning, but that's over and done with. The only thing that still reminds me of it is the intermittent pain left by the bullet that smashed the bones of my arm.”(39).

According to Cathy Caruth, "the term trauma is understood as a wound inflicted not upon the body but upon the mind" (Unclaimed Experience 3). During the bombing of Alexandria, Mahmoud witnessed the defeat of his country and was physically injured in his arm. Mahmoud never complains from physical pain but his wife could see that he sometimes holds his arm and knew that the wound is more painful in cold weather. Mahmoud survives death but his inner psychological wound causes his crisis. As the terrible sandstorm scatters the belongings of two stray camels everywhere, it scatters with it images of different people and past events in Mahmoud's mind. Memories that he has long buried deep in his mind and has managed to conceal with a false heroic image start to protrude. Such burial of past traumatic events recalls Bloom's image of "engraving", whereby past traumatic experiences "remain 'frozen in time' in the form of images, body sensations like smells, touch, tastes, and even pain, and strong emotions"(6).

Mahmoud listens to the guide's reproach and advice to the two stray camels which ran away when the storm broke. "You should have stayed quiet during the storm . . . not run from it to your destruction. Haven't the desert and the caravans taught you anything?"(Taher 44). The guide's moral lesson to the camels not to run away or escape at moments of danger resonates in Mahmoud's mind. Turning to Mahmoud the guide says "as though in self-defence, '[t]his isn't the storm season. It came at least a month early"'(44). Nevertheless, it is the guide's reference to the treachery of the desert that arouses in Mahmoud memories of betrayals. The guide explains to Mahmoud, "I've lived with this desert all my life . . . but it's treacherous. No matter how long you live with it and how safe you feel in it, it can still betray you"(44-45). Mahmoud bitterly answers in a low voice "[n]ot so much as men"(45) and tries to find a safe refuge from those protruding memories in sleep but fails. His agony is 
clear in observing how all the people in the caravan are able "to find peace and sleep in this heat. I alone then was incapable of sleeping"(49). Mahmoud considers Catherine "fortunate. Sleep comes to her quickly, whenever she wants. Unlike me, she doesn't have to battle with it each time"(48).

Finally, Mahmoud's inability to evade recalling past memories leads him to recount his first flashback, "there's no escape from the faces that crowd the emptiness and impose themselves suddenly and importunately"(Taher 50). In a long flashback, he recalls memories of the bombing of Alexandria, betrayal of Urabi and the defeat of his country which causes him a severe injury.

Mahmoud depicts how "[t]he face of Tal'at, friend and companion of my youth, rise to the surface, but with his appearance all the other faces disappear and the roar of the canon reverberates in my ears"(50). The image of Tal'at is usually connected with the bombing of Alexandria in Mahmoud's memory. "Those hours and days with Tal'at remain engraved on my memory no matter how hard I try to erase them" (50). Witnessing "the British ships shelling the fort"(51) clearly traumatizes Mahmoud. He remembers Tal'at's bitter remark when he says "in a choking voice, 'it's slaughter, not war'"(51).

Mahmoud confesses, "I have spent days and years concocting short-lived treaties with myself. No sooner do I tell myself that I did what I had to do than something inside me mocks me, and I run to drink and women"(49-50). Hence, Mahmoud's failure attempts to "dissociate" leads him to alcohol. Herman declares that "[t]raumatized people who cannot spontaneously dissociate may attempt to produce similar numbing effects by using alcohol or narcotics"(Herman 32). While Catherine's childish advice that they should defeat the world amazes him,

how can she claim with such confidence that we shall defeat the world? What weapon could I, for example, have brandished in the world's face when all the rest had put their weapons away? The good ones, like Brigadier General Saeed, were content merely to stick their weapons in their scabbards. The others, though, stuck them in the country's chest. I beheld with my own eyes the stab in the back that broke Urabi, and then I beheld the greater betrayal that followed, right next to my own house, to be precise, in the square that witnessed the glory and the joy. (Taher 48) 
Mahomoud bitterly remembers Urabi's betrayal by the Khedive and the great men of the country a year after the revolution, "and I wept for my country and myself. And Catherine asks me what my crisis is?"(49).

Nevertheless, Mahmoud's failure to remember what has happened to him during two days reveals the severe impact of the brutal bombing of Alexandria by the British troops. "All that remains in my mind of those days is disconnected images. . . . but I don't remember whether I slept or where I slept or what I did exactly during those two days"(54-55). He ironically remembers their encounter with the gangs of Bedouin people and their attempts to stop them from "breaking into the locked shops and plundering them", when one of the men "stands in the middle of the road and asks in astonishment, 'Why are you firing? Didn't you get the orders. ... Will you not carry out the orders to bring down Urabi, who is in a state of mutiny against Our Master the Khedive and bringing ruin on the country"(52). At that moment, the conspiracy against Urabi Basha was clear to both Mahmoud and his friend.

Mahmoud resentfully remembers the evacuation of Alexandria from civilians, "the marching crowds, the crackling of the flames, the weeping children, the wailing women and the insults of the men, who cursed the British, the Khedive, the army and the police at the top of their lungs"(Taher 54). Mahmoud bitterly recalls how some of the men pointed at him, and called him "[t]raitor!"(54). He even justifies their insults, "[t]hey were right: on that day, when their city had been burnt and they had lost sons and fathers, who could sort out traitors from those who had remained true?"(54). Mahmoud reflects upon the painful event "[a]mong the flames of the burning buildings and the chaos, the page on which the courage of the soldiers of the forts and of the people of the city who had fought with them had been inscribed was erased. How, then, could I tell those refugees who insulted me that I alone, had not betrayed them??(54). Up till that moment, Mahmoud was true to himself and to his country. He remembers his friend Tal'at who "had been struck by bullets in his belly and legs but his life was not in danger. (Would that it had been! Would that he had died at that moment when he was true to himself! And would that I had departed with him!"(55). Mahmoud's exclamations reveal bitter lost aspirations and remorse. His grief and lament of bypassed days of glory of himself are quite evident.

After the two days, Mahmoud's transfer to Alexandria is cancelled without explanation and he is ordered by the Italian superior officer to return to Cairo with a request for investigation. "My investigation by Captain Saeed Effendi didn't take long. Conditions in Cairo were quite different from those I had left behind me in Alexandria. The 'mutineers' 
of the latter were heroes in Cairo the Protected"(55). In this first investigation, Mahmoud confesses, "I related everything that I had done. . . . And I presented my testimony regarding all that had befallen Lieutenant Tal'at, who was still being treated in Alexandria. Captain Saeed recorded my statements and ordered that the investigation be shelved and I return to work"(55-56). Mahmoud depicts the different conditions in Cairo where the people are still proud of the revolution. "With everybody else, I followed with pride and enthusiasm what happened in the fighting"(56). "I even neglected to have my deep shoulder wound treated, resulting in a delay in its knitting and mending"(56). At the end of this flashback Mahmoud only refers to the second interrogation, "the interrogation was reopened two months later, by which time everything had changed"(56). Mahmoud does not recount his change of testimony in this flashback. On the contrary he keeps his own heroic image and enquires about the betrayal of others.

All the time I ask myself about the betrayal. I asked myself often then, 'Why were the bashas and the great men who had everything traitors? And why did the little people always pay the price, dying in the war and being imprisoned after the defeat, while the great ones remained free, and great?' I asked myself, 'Why were the little people also traitors?'(56)

Mahmoud bitterly contemplates the guide's words, "[ $[\mathrm{t}$ he guide says the desert is treacherous, just because a storm came out of the season! Come here, and let me tell you what real treachery is!'(57).

The harsh journey through the desert and the threat of death during the sandstorm only reveals part of Mahmoud's crisis. Mahmoud's heroic image is maintained as he reaches Siwa Oasis. Nevertheless, Ibrahim's view of Siwa Oasis being "like no other place and its people are like no other people"(46) anticipates danger. Mahmoud is faced by the hostility of the people towards himself and his wife. Reaching Siwa, Catherine notices the, "looks of hostility" in people's eyes "which they attempted to hide"(Taher 61). Mahmoud confesses, "I came to this oasis hating it and its people and I have come to hate them even more because of their hostility towards me, Catherine and even the troops"(170).

\section{The Impact of Life in Siwa Oasis on the Protagonist:}

The first reference to Mahmoud's lack of courage is depicted after a "beautiful dream"(86) that he recalls nothing of but the face of Dusky Ni'ma. Mahmoud recalls, Dusky Ni'ma is "the one and only, for whom I search in all other women"(50). Mahmoud regrets not well appreciating her before her elopement. Mahmoud contemplates his inability to fight 
for his love, "would I have found the courage to marry her, for example, if I'd found her or if she'd come back to me? The respectable officer marry a slave of unknown parentage? What a scandal!'(96). His final exclamation depicts his failure to stand for his love.

Though the dream wakes Mahmoud in a very good mood, he anticipates danger. "Why do I feel dejected and why is my heart telling me that something is about to happen - that thing which I assuredly

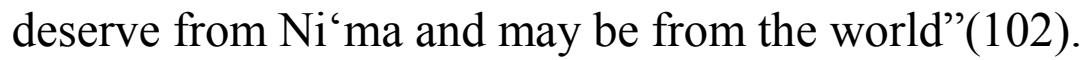

Mahmoud's feelings come true. Accompanying his wife to visit the temple of Umm Ma'bad (referred to as the temple of Umm Ebeida), Mahmoud faces a traumatic experience of stone fall in which he fails to fight. Mahmoud's lack of courage is clearly stated. Mahmoud confesses, "I saw the stone falling on the boy and I rushed forwards with Ibraheem to save the young Mahmoud. At the last instant, however, in the final seconds during which I saw the large stone would hit me too, I stopped. I went rigid with fear where I stood"(147). His fear and helplessness reflects Herman's belief that victims are rendered helpless by overwhelming forces at moments of trauma. Admitting his hesitation, Mahmoud also declares that he has been nearer to the boy than Ibrahim "but Ibraheem passed me with a single bound and flung himself forwards, taking the boy in his arms, pushing him away, and throwing himself on top of him"(147). Mahmoud further confesses how after "coming to his senses," he threw himself on top "but it came too late - after I'd made sure my own life was safe and after the stone had smashed Ibraheem's leg"(147-148). Mahmoud's confession depicts his lack of courage to face death. His cowardice and his inability to fight are evident.

The impact of Mahmoud's failure to fight at the moment of the falling stone triggers another failure to fight in his memory and reminds him of his real crisis, "My crisis? Catherine asks me about my crisis? I ask myself about it?"(143). With the falling of the rock, Mahmoud's heroic image that he boasts in front of everyone, falls as well. "There was my crisis. In one instant, the crisis of Mahmoud Abd el Zahir was made plain. . . . In a few seconds, the false image of the past that I'd drawn for myself fell away and with it all my hypocritical thoughts on life and death"(143). The catastrophic event drives Mahmoud to face his earlier hypocritical claims about death, "when I saw it descending, in the shape of a stone, from the sky, I was terrified. Even when it was a duty that I had absolutely to obey, I behaved like a coward and let another perform it. Is this then my reality?"(151). His cowardice and failure in saving the boy reminds him of his early shameful failure to fight for his country and 
his false testimony during the second investigation. His disgrace that he tries to conceal under the guise of a victim clearly appeared,

I boast to myself of a heroic past and deliberately forget the moment of ignominy. I think of myself as being unfairly treated and a martyr in the police, when I may be the worst of them all. The mutinous officer! I liked the role, so I believed myself. Perhaps I also deliberately passed this legend to Catherine from the first days of our relationship. (Taher 143)

In an honest confrontation with himself, Mahmoud confesses his trauma saying, "let's face things now; the time for deception is over"(143). He asks himself "[w]hat precisely did I do during the revolution? I ran from the beach to the hospital transporting the wounded and the dead?"(143). He confesses that he has not been an exception and that all men and women have done the same. Remembering his encounter with the Bedoin people, Mahmoud corrects his false heroic view of his wound.

You fired the Bedouin after they opened fire on you? What else would anyone have done to defend himself? The war in which thousands died left you with an injury as a result of a bullet in your shoulder that neither ended your life nor threatened it you didn't even receive the bullet while fighting the enemy who were invading your country. No, it was like a wound received in some fleeting accident on the road, yet, you lived your life thinking of your wound as a medal worn under the skin and a badge of glory. Now all that's gone, so what's left of your image? (147)

Mahmoud's disgraceful testimony in the second investigation conducted by a Circassian head of the commission causes his severe injury but he used to conceal his cowardice under a heroic guise laying the blame on Tal'at's testimony. "This persecution served my interests, however: by degrees I created for myself the image of the forgotten victim, the man with a cause"(147). Remembering his earlier attitude to his friend's treachery and how he made use of it to enhance his false heroic image, Mahmoud confesses, "There remains the betrayal of Tal'at, your colleague and old friend, which you have likewise continued to carry inside you as an emblem of the way the world has let you down and betrayed you"(144). Mahmoud contemplates, "even if I don't forgive him, why should I blame him?"(145). He explains, "I didn't understand the secret of why he'd turned against me until Captain Saeed explained to 
me later, in a whispered confidence. . . . In those days everybody was looking for something that would save him from prison or expulsion from his position"(145).

After the stone fall Mahmoud corrects his view of Tal'at's shameful testimony, "A traitor, but honest with himself. He lied about me but not to himself"(145). Like Tal'at, Mahmoud betrayed his public cause and lied in his testimony. He denied his belonging to the mutineers and testified against Urabi Basha betraying himself and his country. Mahmoud lies in answering the question: "Did you support Ahmed Urabi and his followers?" saying: "On the contrary, I was one of those who most bitterly condemned the actions of those miscreants"(146). Though both men denied their belonging to Urabi, Mahmoud now confesses that unlike his friend, he lied to himself as well. Mahmoud confesses, "In what way am I better than Tal'at? Why do I deliberately not think of the moment of ignominy and betrayal? It was two short answers I gave during the commission's interrogation, which I constantly push aside in my memory but which continue to lurk inside me like embers"(Taher 146).

In his attempt to protect Mahmoud, Captain Saeed has "pointed out the weakness in [his] statements of the first investigation, which he had conducted himself"(146) and has "suggested these answers"(146). Mahmoud confesses, "I added my own contribution at the investigation and described them as 'miscreants'!"(146). Mahmoud faces himself when he admits "[t]he price was small - to deny the truth, to betray and save my skin. So I accepted the bargain"(147).

Mahmoud confesses the traumatic impact of his testimony.

Following the investigation I lived for months in a state of self-disgust. I drank like one running after death. Then came the blessing of forgetfulness and I pushed out of my memory the disgrace of cowardice and betrayal. An entire life during which my main concern has been to chase away the memory every time it raises its head, and to deny it. (147)

Nevertheless, Mahmoud is uncertain about when he has acquired such a detestable trait. "I wasn't born a coward, though. Whatever I've said about myself in Alexandria, I faced death at every moment there without thought of flight. . . . When did I change?"(151). Mahmoud first lays the blame on Saeed claiming that the moment of change is "that moment when I took Saeed's advice and denied everything in the investigation?"(151). Then Mahmoud corrects himself for he is no longer looking for excuses or justifications. 
But I obeyed Saeed only because I would have wanted in the depths of my heart to do what he advised, even if he'd never spoken. I could have chosen the truth. Others did. . . . I am the one who chose, of my own free will, to betray and abandon, just as I abandoned Ibraheem and left him to run the risk of getting killed. (152)

Mahmoud admits his terrible state of helplessness after the incident of the stone fall on both physiological and psychological levels. "I must have spent entire days standing next to Ibraheem's bed. . . I watched him impotently, aware that all that pain would have been mine if I had gone forwards instead of him"(148). Catherine's advice "you shouldn't implicate yourself in the killing of poor Ibrahim"(150), reminds Mahmoud of his cowardice, "I didn't tell her I was already implicated. There was no witness but me to those seconds and perhaps even Ibraheem hadn't noticed"(151). During the cauterization of Ibraheem's leg, Mahmoud experiences the same pain. He enquires "was I dreaming? Had I gone mad? Fire burnt the skin of my leg in the very place where Ibrahim's was being cauterized. I shuddered and turned my face away, placing my hand over my mouth so that I wouldn't scream like him"(154). The Bedouin who has been treating Ibrahim's leg says that Ibraheem is cured and will be back on foot after two days. But as he declares that Ibrahim will limp for the rest of his life, Mahmoud remains standing where he is. He confesses his feelings saying, "I was certain that if I moved, I'd limp. For two days at the police station and at home I walked with slow steps so that no one would notice anything. Then the pain in my leg improved"(Taher 155).

Following the incident of the stone fall and the treatment of Ibrahim, Mahmoud starts deteriorating. Mahmoud confesses the decline in his relationship to Catherine, "since we got to this oasis something has been broken"(248) and he later confesses, "I think that, inside, I've finished with her"(221). His inability to rest is increased by haunting nightmares "[a]nother dark dawn and two nights without sleep"(290), Mahmoud bitterly thinks. Catherine also notices the change that occurs to his appetite, he "used to have an appetite" but now he "hasn't been able to finish his meals... . he swallows his food with difficulty as though he has something in his throat"(265).

Mahmoud's burdens are further multiplied by a new betrayal near the end. He discovers that his doubts in Wasfi, the newly sent officer, are true when he reads a letter sent by the department of Directorate of the Special Order thanking Wasfi for his "well-documented report"(293). 
Mahmoud takes a number of uncalculated decisions that he later regrets. He uses force with the people of Siwa Oasis. Mahmoud has been lately rebuked by the ministry for his failure to fulfill his enforced duty as District Commissioner of Siwa Oasis. "Reproaches, reproaches, reproaches. Then advice on how to do things. I am to use determination and strength with the native population because leniency will not work, as experience has demonstrated"(168). Following the ministry's advice, he fires the cannon "just to terrorize them and the miracle was achieved"(197). Nevertheless, Mahmoud condemns his "wretched destiny"(198) for having to use force with the people of Siwa to whom he feels he belongs more than the British occupants of his country. $\mathrm{He}$ bitterly meditates, "I will continue down the road that has been laid out for me and which I tried to avoid. I shall imprison, and possibly flog, to collect the taxes, as did my predecessors. ... following the advice, which I despised, of Mr Harvey, whom I despised for giving it"(198). Later, he also receives an anonymous written warning from one of the Siwian people (agwad) saying "[t]he district commissioner should not go out alone on night patrol these days. People are waiting to kill him"(246).

Mahmoud's attitude towards Wasfi near the end reveals a final attempt towards gaining his self-respect. Knowing that Wasfi greatly admires the ancient Egyptian civilization, Mahmoud asks Wasfi "[c]annot the descendants be as worthy of ruling the country as their grandsires?"(286). Hearing Wasfi denying Egyptian rule and "defending Britain's occupation of his country!"(239) encourages Mahmoud to defend his country. Though Mahmoud is sure of Wasfi's betrayal, he acts courageously when he hears Wasfi's disdainful view of Urabi. Mahmoud states "Listen Wasfi. . . . Urabi Basha had more honour than ten khedives put together. And Lieutenant Colonel Mohamed Ebeid had more honour than all the traitor khedives and bashas who sold us to the British"(288). Nevertheless, Mahmoud's courage in facing Wasfi does not redeem him. Mahmoud is aware that his brave attempt to voice his belonging to the revolution and respect for Urabi Basha comes "twenty years too late"(288). Remembering his early testimony, Mahmoud rebukes himself saying, "there's no call to pat yourself on the back in front of Wasfi or anyone else"(289).

Mahmoud finally faces his own flights in a long confession to himself, depicting his own problem and his failure to fight:

The problem is precisely you, my dear major! It's no good in this world being half good and half bad, half a patriot and half a traitor, half brave and half a coward, half a believer and half a womanizer. Always in the middle.... I wanted to 
save young Mahmoud but in the midst of the attempt I let Ibrahim break his leg. I was a supporter for a time of a nation and the revolutionaries, and when it came to the test I denied them. And then I did nothing. Never was I one person, complete on the inside. . . I sold myself for no price at all, content to be bitter at myself, the British and the whole world without knowing what I'm asking for. (Taher 220-21)

Mahmoud's burdens kept increasing until his helplessness defeated him. His helplessness and his constant flights when facing lifethreatening events lead him to his dramatic end. Arifa Akbar shows that in Sunset Oasis, the author has created a "tragic figure" whose final “devastating act ... represents an anti-hero's desperate desire to become a hero"(Akbar 2).

At sunset Mahmoud reaches the temple determined to put an end to his suffering, "[t] his nightmare had to end"(Taher 303). He explains to his staring horse, "it's not my fate to be saved. If pain, toil and thrusts of betrayal and injustice were a price for salvation, I would have been saved"(303). Mahmoud uses the dynamite, sent by the British occupants to help him in gathering the enforced amounts of taxation, in burning the temple and ending his own life. "On, holy fire! Devour the holy temple so that we can be done with all these fables!'(304).

Though unjustified in his final desperate act, the reader understands Mahmoud's reasons for burning the temple. Mahmoud rejects the colonial policy which glorifies Ancient Egyptian civilization and at the same time denies Egyptians self-rule. The British policy is clear in Wasfi's view, "[w]hen the common people interfere in government, chaos follows, and weakness"(287). Mahmoud exclaims to himself, in a final look at the temple, "[s]o this was the glory the British were revealing to us so that we could know we had once been giants and were now dwarves!"(303). His final decision is clearly stated, "[n]ot a trace must remain of the temple. We had to be done with all the stories of the ancestors if the descendants were to wake from their delusions of greatness and their false complacency. One day they'd thank me"(303304).

At the last moment he questions his ability to face death courageously or whether he will fail to fight again and escape. "Why, then, am I waiting outside? Is cowardice going to take me again at the last moment? No! I'm coming! Into the temple!'(304). Mahmoud finally dies thanking whoever has come to his rescue for "coming too late"(305). 


\section{Conclusion:}

The journey through the desert and life in Siwa Oasis do not help Mahmoud to be healed from his traumatizing injuries. On the contrary, it increases his helplessness. According to Bloom, "[T]he traditional definition of masculinity does not allow for helplessness - you cannot be a victim and be masculine"(Bloom 14). Mahmoud's helplessness drags him into other injuries until it finally leads him to end his own life. Mahmoud confesses his helplessness near the end, "I didn't choose my life. I didn't choose to come to this oasis"(Taher 301).

Bloom concludes her study by depicting the suitable environment that helps in the recovery of traumatized people. "Creating Sanctuary refers to the process involved in creating safe environments that promote healing and sustain human growth, learning, and health"(Bloom 15). Bloom depicts a fundamental change towards traumatized human beings in order to help them recover saying.

One fundamental attribute of Creating Sanctuary is changing the presenting question with which we verbally or implicitly confront another human being whose behavior we do not understand from 'What's wrong with you?' to 'What's happened to you?'. . . moving us toward a position of compassion and understanding and away from blame and criticism. (15)

Bloom's assumption about the human need of safe environments to heal is useful. She explains that safety includes "not just physical safety, but psychological, social and moral safety as well. ... Safety involves not just prohibitions against violence to others but also prohibitions against the short and long forms of self-destruction, i.e. suicide"(15-16).

Bahaa Taher's Siwa Oasis is not the proper place to heal for Mahmoud. Far from Bloom's recommendations in "Creating Sanctuary", the author's portrayal of the hostility of the place and the people anticipate the dramatic end. Catherine's constant enquiry "what is your crisis?"(Taher 46), reveals her failure to Mahmoud. The hostility of the people is far from the "compassion and understanding" suggested by Bloom. The harsh and suffocating environment of Siwa Oasis is not the "safe environment" for Mahmoud's healing. The new betrayal of the British government represented in the person of Wasfi stimulates the memories of earlier betrayals and aggravates the remorse at earlier flights during his life. 
In portraying the traumatic impact of the protagonist's failure to fight in moments of danger, Bahaa Taher manages, in Sunset Oasis, to delineate the psyche of a traumatized man whose trauma is not "the encounter with death" as Cathy Caruth depicts but "the ongoing experience of having survived it"(Unclaimed Experience 7). 


\section{Works Cited}

Akbar, Arifa. "Sunset Oasis: A Vision of Freedom in Egypt's Colonial Wilderness."

$<$ https://www.independent.co.uk>

(2009)

Aspden, Rachel. "Sunset Oasis by Bahaa Taher." The Guardian. November (2009) <https://www.theguardian.com/profile/rachelaspden>

Berger, James. "Trauma and Literary Theory." Contemporary Literature. Vol.38, No. 3 (Autumn,1997), pp. 569-582 $<$ https://www.jstor.org/stable/pdf $>$

Bloom, Sandra L. "Trauma Theory Abbreviated." From The Final Action Plan: A Coordinated Community Response to Family Violence. October (1999) < $<$ https://www.scribd.com>

Caruth, Cathy. Trauma: Explorations in Memory. Baltimore: Johns Hopkins University Press, 1995.

Caruth, Cathy. Unclaimed Experience: Trauma, Narrative, and History. Baltimore: Johns Hopkins University Press, 1996.

Edkins, Jenny. Trauma and the Memory of Politics. Cambridge: Cambridge University Press, 2003.

Herman, Judith L. Trauma and Recovery: The Aftermath of Violence from Domestic Abuse to Political Terror. London: Pandora, 1992. <http://issuu.com>

Irvine, Lindesay "Existential crisis novel wins first 'Arabic Booker'." March

http://www.guardian.co.uk/books/2008/mar/11/news.lindesayirvi ne

Kattaya, Mona. "Identity Quest: When East Meets West in Bahaa Taher's Sunset Oasis, A Post-Colonial Reading”. East Meets West: Innovation and Discovery: Official Conference Proceedings of The IAFOR International Conference on Arts \& Hummanities, Dubai, UAE 26-28 February 2017 <https://papers.iafor.org>

Luscombe, Karen. "Review: Sunset Oasis, by Bahaa Taher." The Globe and Mail. January <https://www.theglobeandmail.com> 
Mahmoud, Rania M. Fictions of Revolution: Empire and Nation in Lawrence Durrell, Naguib Mahfouz, John Wilcox, and Bahaa Taher. 2014. University of Washington, $\mathrm{PhD}$ dissertation. ProQuest, $\leq$ search.proquest.com/docview/1608992559?accountid+178282 $\geq$

Marder, Elissa. "Trauma and Literary Studies: Some Enabling Questions." Reading On. Vol.1 (2006) $<\underline{\text { http://www.academia.edu/2334946> }}$

Qualey, M. Lynx. "Review of Sunset Oasis" The Quarterly Conversation. December $<$ http://quarterlyconversation.com/tag $>$

Taher, Bahaa. Sunset Oasis. Translated by Humphrey Davis, Egypt: Dar El-Shorouk, 2009.

Terr, Lenor. Too Scared to Cry: Psychic Trauma in Childhood. New York: Harper and Row, 1990.

Whitehead, Anne. Trauma Fiction. Edinburgh: Edinburgh University Press, 2004. <https://www.jstor.org/stable> 


\section{المواجهة أو الهروب: دراسة "واحة الغروب" لبهاء طاهر مع التركيز على نظرية الفجعية}

مستخلص:

تتسم رحلة بحث الإنسان من البرائة إلى الخبرة بقدرته على مواجهة الصعوبات المختلفة. بعض التجارب تكسب الإنسان درسا مستفادا بينما تصيب التجارب الأخرى الإنسان بجرح غائر.و يختلف رد فعل البشر تجاه التجارب المفجعة. ففى أوقات الخطر يتمكن بعض البشر من 'المواجهة، من أجل البقاء بينما يلوذ البعض الآخر بالفرار حين يتعرضون لمواقف قد تهدد حياتهم. و يعانى الأشخاص الذين يفشلون فى 'المواجهة، من العجز وضعف الحيلة حين يتعرضون لمواقف خطر متكررة. و قد أوضح لينور تير قائلا: "تحدث الفجيعة النفية حين يتعرض الإنسان الى صدمة عاطفية هائلة، حادة و غير متوقعة أو يتعرض الى مجموعة من الصدمات الثديدة و التى تضرب الإنسان من الخارج. و تكون الأحداث المفجعة خارجية و لكنها سر عان ما تدمج فى الذهن"(^). يهدف هذا البحث الى تطبيق نظرية الفجيعة على رواية "واحة الغروب" لبهاء طاهر و التى حصلت على الجائزة العالمية للرواية عام ^ . .. . و تدور أحداث الرواية حول محمود عبد الظاهر الذى تم إرساله من قبل الإحتلال البريطانى مأمور الو احة سيوة النائية و ذلك كعقوبة لإشتر اكه فى ثورة عرابى فى نهاية القرن التاسع عشر. يعانى محمود من مجمو عة من الصدمات الحادة نتيجة ضرب بريطانيا للإسكندرية، هزيمة عر ابى، خيانة الملك و شهادة صديقه طلعت. بينما تكمن معاناة محمود الحقيقية فى شهادته التى أدلى بها فى التحقيق الثانى حيث فنثل فى 'المواجهة، من أجل وطنه. و بالتركيز على تأثير الرحلة فى الصحر اءو و الحياة فى واحة سيوة فإن الدراسة الحالية تهدف الى تحليل الأساليب القصصية التى أستخدمها الكاتب لإسترجاع لحظات الضعف القاسية التى أوقعت داخل محمود جروح غائرة حتى نهايته الدر امية.

$$
\text { الفجيعة _ المواجهة أو الهروب - PTSD - "واحة الغروب" }
$$


الجزء الثاني

العدد العثرون لسنة 9 ب.

مجلة البحث العلمي في الآداب 
"An Ekphrastic Encounter: A Comparative Study of Elizabeth Jennings' Rembrandt's Late Self-Portraits and Rembrandt's Last Self-Portrait"

by

Iman Farouk EI Bakary

Associate Professor

Department of English Language and Literature

Faculty of Arts

Ain Shams University

2019

An Ekphrastic Encounter: A Comparative Study of Elizabeth Jennings' Rembrandt's Late Self Portraits and Rembrandt's Last SelfPortrait 


\begin{abstract}
This paper compares Elizabeth Jennings' ekphrastic poem entitled Rembrandt's Late Self-Portraits and Rembrandt's last self-portrait. It is a close reading of the poem in view of the concept and praxis of ekphrasis, which is generally defined as the rhetorical representation of a work of art. The poet's choice of self-portraiture is highly significant when one bears in mind Jennings' and Rembrandt's respective lives and careers. The decline from vibrant youth to old age, and the fear of death and a waning creative ability: all seem to add to the attraction of the poet towards the painter. The poem is a typical example of that admirable, ekphrastic synthesis in which the boundaries between the two "sister arts" of poetry and painting are crossed. Indeed, both representational modes work together in their quest for self-knowledge and a dignified selfassurance.
\end{abstract}

Key-words: Ekphrasis - Elizabeth Jennings - poetry - Rembrandt - selfportrait

المحاكاة الثعرية للقتون التشكيلية : دراسة مقارنة لقصيدة ((البورتريهات الأتية الأخيرة

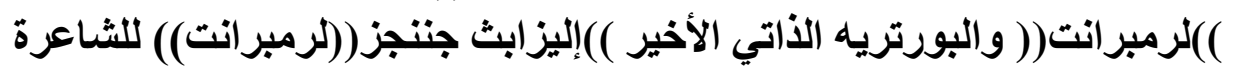




\section{ملخص}

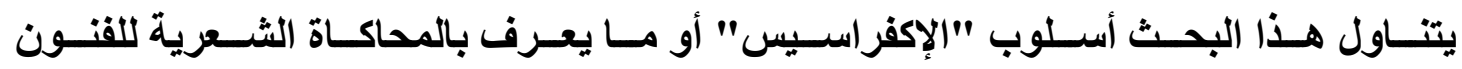

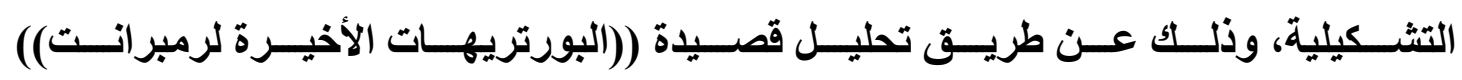

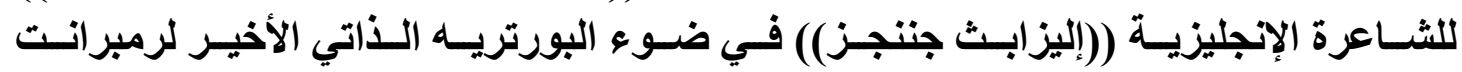

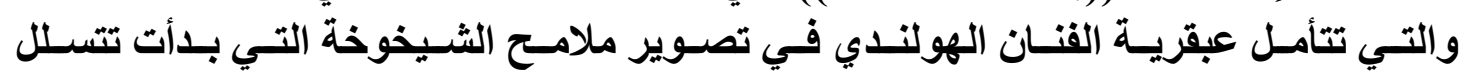

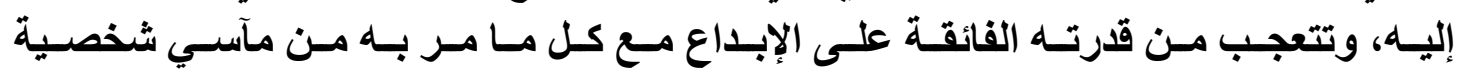

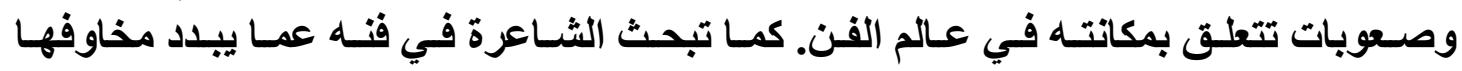

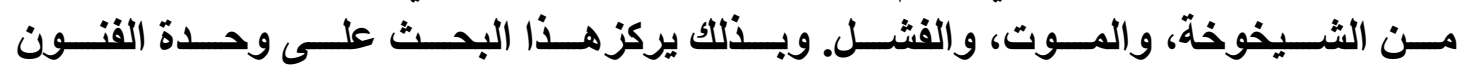

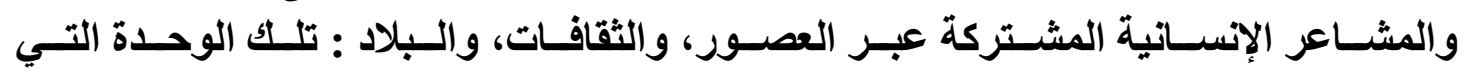
تعتمد على المحاكاة الشعرية للفنون التشكيلية . 


\section{An Ekphrastic Encounter: A Comparative Study of Elizabeth Jennings' Rembrandt's Late Self-Portraits and Rembrandt's Last Self-Portrait}

This paper is an attempt to examine Rembrandt's Late Self-portraits by English poet, Elizabeth Jennings (1926-2001). It is an ekphrastic poem that creates a direct link between the tragic but successful life of the great Dutch painter, Rembrandt (1606-1669), and that of the great poet whose work raises universal questions about the ordeals of old age. As one reads Jennings' poem, one discovers that the contemplation of Rembrandt's depictions of himself towards the end of his life is, in fact, a projection of the poet's striving to come to terms with her mental illness and old age. Thus, the paper attempts a comparative study of Jennings' poem and Rembrandt's own last self-portrait. The comparison yields a professed case of dynamic relation between the visual and the verbal whereby ekphrasis is rendered as a power technique of literary representation.

In her Preface to Modern Ekphrasis (2013), Emily Bilman goes beyond the Oxford definition of ekphrasis as "the rhetorical description of a work of art". (9) She quotes Jean Hagstrum's etymology of the Greek word ekphrazein as consisting of "ek" meaning out and "phrasis" meaning to speak. Thus, ekphrasis means "to speak out or tell in full". (9) Bilman goes on to refer to Plato's and Aristotle's respective notions of imitation or mimesis. She explains that while Plato emphasized imitation as that of "an ideal metaphysical form", Aristotle held that "imitation meant the creation of new artworks in different domains, and mainly, in the dramatic arts". (13) Further emphasizing the relation between poetry and painting, Bilman remarks that for Aristotle, "both poetry and painting imitate nature by their own distinctive media, and achieve their particular unified shape and purpose which, when completed, generate and obey their own rules". (14) Still referring to Aristotle's distinction between poetry and painting, Bilman states that poetry imitates life through the use of music and rhythm, whereas painting does this through shapes and colours. (27) Besides, she understandably sees an analogical relationship between both arts. She states that "poetry, as word-music, is to art what sound is to nature; and painting as coloured shape, is to art what form is to nature". (10) She further explains the relation between the two arts as follows: 
The combination of sounds in a poem, like the arrangement of colours upon a canvas, evokes a unity that stirs our aesthetic feeling. Poetic words do not simply denote, but connote reality and carry a symbolic value. Paintings represent "thing" through colours and shapes. The dialogue between painting and poetry is situated in artistic imagery, which is shaped differently, in each media[um].

Moving from the Classics to the Renaissance conception of ekphrasis, Catherine Belsey refers to Shakespeare's The Rape of Lucrece in her article entitled "Invocation of the Visual Image, Ekphrasis in Lucrece and Beyond". Defining ekphrasis as "the representation in words of a pictorial representation", (4) Belsey interestingly states that ekphrasis in Shakespeare's work

constructs an uncanny relay of gazes - from the imagined eyes of the Trojans sadly regarding the predatory Greeks, to those of Shakespeare's protagonist [Lucrece] as she laments her violation, and on to those of the putative viewer of an imagined painting, and then, perhaps, to the eyes of Shakespeare's reader invited to participate in this newly widened awareness of loss.

Indeed, Shakespeare's words summarize the effect of viewing a tragic painting on the already devastated heroine in Lucrece's utterance, "There might you see disaster, and understand one tragedy more deeply by perceiving it in terms of another". (qtd. 4) Thus, by comparing the moments of the Roman heroine's destruction to that of a similar, even older situation from antiquity, a visual representation in a story, or a poem, as is the case with Jennings, "can bring the past into the present without surrendering the distance between the two". In a statement that certainly applies to Jennings' delineation of Rembrandt's late selfportraits, Plutarch affirms that the best writers "turn the reader into a spectator", thus echoing Horace's often quoted influential observation, seminal in the Renaissance, "Ut picture poesis" (as painting, so poetry). (18)

Moreover, stressing the importance of the rapport between painting and poetry in Renaissance culture, Belsey refers to Shakespeare's ekphrasis as affirming the artist's miraculous creation of a world so real that we become not mere observers but partakers of the painted world, so that art 
becomes "an illusion of presence without words". (22) In addition, she quotes Ben Jonson's statement, "Whosoever loves not picture is injurious to truth, and all the wisdom of poetry". (20)

On reading Elizabeth Jennings' poem about Rembrandt's selfportraits, one has to keep in mind the paragone that has existed since Plutarch's time about the question of the superiority of art or painting. If Plutarch held that "painting is mute poetry, poetry a speaking picture" (12), Leonardo Da Vinci "reformulated the axiom accordingly: if painting is mute poetry, poetry is blind painting". (13) As for Ben Jonson's affirmation that the writer's pen was nobler than the artist's pencil, "for that can speak to the understanding, the other, only but to the sense", Belsey reminds us of Hieronimo's question to the artist, "Canst paint a doleful cry?" This significant question seems to support the view that "Shakespeare's invocation of the visual arts [as in The Rape of Lucrece] is designed to affirm the superiority of the writer, aligning the poetplaywright with the traditionalists, rather than Derrida and Mitchell". (15) Yet, Shakespeare seems to contradict this view in Lucrece's line quoted by Belsey: "To see sad sights moves more than hear them told". (I, 1324, qtd 16) In fact, Catherine Belsey significantly points out Shakespeare's own solution to this debate, again through Lucrece's statement to the effect that poetry can indeed borrow images from works of art and give them a "lamenting tongue". Addressing the painting, the heroine exclaims:

Poor instrument, without a sound,

I'll tune thy woes with my lamenting tongue...

So Lucrece[,] set- a- work, sad tales doth tell

To pencill'd pensiveness and colour'd sorrow:

She lends them words, and she their looks doth borrow.

(qtd 17)

Therefore, in my opinion, Belsey's analysis is an important one. It certainly applies to Jennings' affinity to and empathy for the aging artist 
in her self-reflective poem about Rembrandt's late self-portraits. Belsey thus rightly states that poetry and painting work together; Lucrece lends her 'lamenting tongue' while borrowing the painting's 'colour'd sorrow'.

On the other hand, in his Iconology (1986), W.J.T. Mitchell seeks to shift the paradigm of opposition between language and art in the light of Derrida's Of Grammatology by stating that an image is "Nothing but another kind of writing, a kind of graphic sign that dissembles itself as a direct transcript of that which it represents". (14) Thus, Belsey makes the distinction that "works of art are held to show the world as it actually is. Language ... meanwhile, is thought to interpret the world". Thus, the opposition between visual and verbal representation "sets sensation against intellect, innocence against judgment". Or, as Mitchell asserts, "the paragone or debate of poetry and painting is never just a contest between two kinds of signs, but a struggle between body and soul, world and mind, nature and culture". (qtd 15) On the other hand, though Lessing argues that poetry is temporal while painting is spatial, Mitchell sees this distinction as effective only at a primary level. However, when representation occurs indirectly, "the borders between the two arts are lessened and a dialogue between life and art can be established. Painting represents temporal actions directly through bodies, and poetry talks about bodily forms indirectly through action". (15) Moreover, Belsey's significant thesis of the reciprocal relationship between word and image is summarized in her statement:

Acknowledgment with Mitchell and Derrida that words and images are both modes of representation would permit due attention to the distinctions between them, without cementing these as opposition, while releasing us to recognize the opportunities that arise from combining their respective strengths. (18)

From the above, it can be discerned that ekphrasis is not about the supremacy of one form of artistic representation over another. In fact, a close reading of Elizabeth Jennings' Rembrandt's Late Portraits, inspired by the artist's touching self-portrayal of himself as he approaches his death, certainly proves the significance of ekphrasis as a unifying synthesis between poetry and painting. Moreover, it strengthens my belief in the familial ties among the "sister arts" of poetry, painting and music, among others, and their profound expression of, and 
preoccupation with the human condition in general, and the artist's suffering in particular.

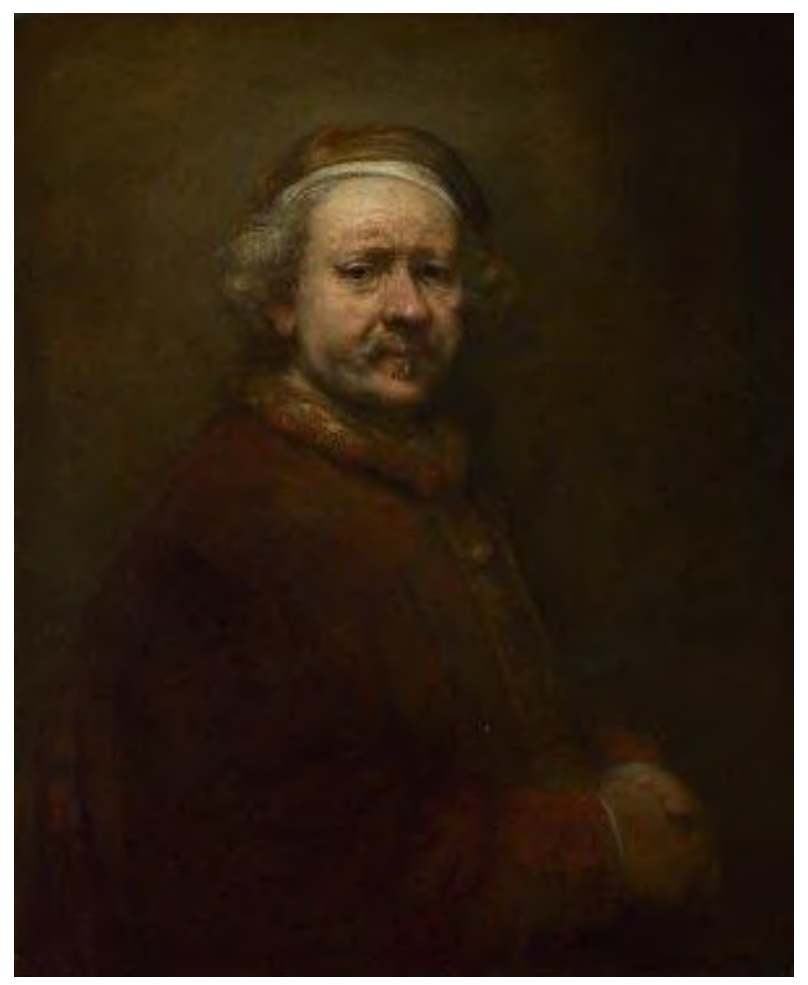

Rembrandt's last self-portrait (1669)

On examining Elizabeth Jennings' poem Rembrandt's Late Self Portraits, the meaning of Bilman's statement that ekphrastic poems are both "referential and self-referential" becomes clear. (10) So does her assertion that "The artist's imagination and interiorized perceptions must meet the viewer's [Jennings'] inner world for communicative interchange to occur". Moreover, describing our role as readers of an ekphrastic poem like Jennings', she states that

In an ekphrastic poem, the reader tries to discover the mimetic relation that links the poem to the painting, the ekphrastic dimension that evokes the painting's impact on the poem, and the divergences that result in the painting's transcription into the poem. Like a movie watcher, the reader also tries to fill the gaps, left open by the transcription of the painting into a poem. (17)

One wonders at the poet's fascination with Rembrandt's late selfportraits, especially the one he painted before his death in 1669 . What 
drove her to engage in a one-sided dialogue with that genius, praising his mastery and dignity despite calamity? Jennings writes:

You are confronted with yourself. Each year

The pouches fill, the skin is uglier.

You give it all unflinchingly. You stare

Into yourself, beyond. Your brush's care

Runs with self-knowledge. Here

Is humility at one with craft.

There is no arrogance. Pride is apart

From this self-scrutiny. You make light drift

The way you want. Your face is bruised and hurt

But there is still love left.

Love of the art and others. To the last

Experiment went on. You stared beyond

Your age, the times. You also plucked the past

And tempered it. Self-portraits understand,

And old age can divest,

With truthful changes, us of fear of death.

Look, a new anguish. There, the bloated nose,

The sadness and the joy. To paint's to breathe, And all the darknesses are dared. You chose What each must reckon with. 
To understand how Jennings' poem about the old Rembrandt is "selfreferential", one needs to mention some biographical information about her. It is well established that Jennings was the only female member of "The Movement", which comprised such distinguished poets as Fuller, Robert Conquest and, above all, Philip Larkin. These poets produced formally disciplined verse that was mostly characterized by being antiromantic and sardonic. However, though Jennings achieved notoriety and was a celebrated writer by age thirty, her fame as a Movement poet "proved a dead end". (Gioia 2) In his article praising Elizabeth Jennings' poetry (2018), Gioia states that though she "shared The Movement's commitment to clarity and traditional form", she had to break with her male counterparts. Being less conservative, a woman and a devout Roman Catholic writing emotionally direct poetry about love, art, and religion, she "had little in common with their detached and ironic attitude toward experience”. Providing great insight into Jennings' personal ordeals, which, in my opinion, bear great resemblance to Rembrandt's, Gioia enumerates some of Jennings' personal impediments. Among these were physical and emotional feebleness, the inability to sustain a practical career, failed love relationships, and mental illness for which she was hospitalized. At the age of forty, Elizabeth Jennings had sunk into poverty, "rescued only by the occasional publisher's advance or literary prize. Alone and destitute in old age, Jennings moved from one shortterm lodging to another, a shabby, eccentric haunting Oxford cafés". After a series of suicide attempts and hospitalization for mental illness (3), Jennings emerged as "a vulnerable and chastened person. Her youth was over, and her resources drained. She would never marry nor enjoy a reliable source of income". Besides, her shabby appearance and her breakdown caused her to be mocked by the press and ignored by critics despite having won the WH Smith Literary Award in 1987 and the title of Commander of the British Empire in 1992. However, this brought about a major change in her work. "Her language and meter relax[ed], her perspective shifted from an essentially thinking poet to a poet of feeling and suffering". Above all, her poems seemed to focus on the themes of childhood, old age and death. Her concern with others after her psychological crisis and breakdown became predominant features of her verse. As Timothy Gardner (2002) points out, "Her final years were far from peaceful, although to the end her poems sought peace, resolution 
and the friendship she prized so highly and understood so clearly". (7) Even as a young, thirteen-year old girl, Elizabeth had been extremely moved by the outbreak of World War II. Commenting on this feature, Grevel Lindop, in his Obituary of Jennings in The Guardian (2001), writes, "Spiritual concerns and a sense of vulnerability, often issuing in a profound sensitivity to the suffering of others, would become important elements in her output".

On the other hand, the great Dutch painter, Rembrandt, emerges as one of the greatest visual artists in the history of art and perhaps the most important in Dutch art history. His works include historical, biblical, allegorical, mythological and natural landscape themes. Besides, he produced numerous portraits and self-portraits which documented the different stages of his own life. Susie Hodge (2013) describes his paintings as "imbued with a sense of mystery through his warm and subtle use of chiaroscuro - the employment of light and shadow". (Art 18) Besides, he was one of the first artists to employ the technique of painting "directional brush-strokes that follow the direction of the objects being painted". Thus, the viewer could see his brush marks, which was an important innovation. Besides, in his later paintings, he occasionally used his palette knife to create broader marks. Rembrandt's more significant contribution was as a renowned portraitist. He did not merely paint the outward features of his models but also "exposed their underlying character. This understanding of humanity, along with his skill in portraying it, is one of the key issues that has made him so revered". (78)

During the late phase of his life, which is the focus of Jennings' poem, he suffered many personal tragedies and financial hardships. Consequently, in his late self-portraits, Rembrandt "is far less selfassured, far more melancholy, far more resigned, far more reflective, than in the earlier self-portraits". (Lackey 2006) In fact, Jennings' description of the artist's face as "bruised and hurt", comes as no surprise if one bears in mind that his son, Rumbartus, died aged two months in 1635, his daughter, Cornelia, died when three weeks old in 1638, his second daughter, barely one month old in 1640, and his first wife, Saskia whom he often painted, died in 1642, a year after giving birth to his only son, Titus. Moreover, his second wife, Hendrickje, passed away in 1663, 
followed by his only son, Titus, who died in 1668, leaving a baby daughter. The artist himself died in 1669 within one year of his son's death, and was buried as a poor man in an unknown grave.

Yet, despite all personal tragedy and bankruptcy after a life of fulfillment and prosperity, Jennings observes, "But there is still love left. / Love of the art and others". It is remarkable that Jennings' own work shows that, like Rembrandt, she remained as prolific and as benevolent as ever, striving to maintain her dignity despite all calamity. Though Dana Gioia holds that her early oeuvre could be viewed as stronger and more consistent, which is not the case with Rembrandt whose late works are still masterpieces, Gioia still ranks the poet "among the finest British poets of the second half of the twentieth century". (2) Indeed, he regards Jennings as the best Catholic poet since Gerard Manley Hopkins", and praises her ability to write superb poems in all the stages of her life. Similarly, as Esther-Lee Marcus and A. Mark Clarfield (2002) point out, though life became harder for Rembrandt, "the highest beauty of life lived on in his heart and from that arose better and more essential projections on his canvas. From his last self-portrait, a harmonious soul looks at you, a personality that has found equilibrium in his creation". (12)

It is interesting to note that seventeenth century painters, as Marcus and Clarfield elaborate, gradually turned to the depiction of elderly figures as worthy in their own right, and not just as allegorical figures. (4) Influenced by Caravaggio's realistic delineation of ordinary people, "Rembrandt depicted himself in old age with honesty". This is perhaps what Jennings admires most in Rembrandt's realistic depiction of himself, as he bravely confronts his physical deterioration with dignity. Referring to the gradual process of aging portrayed in his late selfportraits, she writes:

You are confronted with yourself. Each year

The pouches fill, the skin is uglier.

You give it all unflinchingly.

In fact, Marcus and Clarfield (1968) quote Muller (1968) who states that "He [Rembrandt] was fascinated by skins tanned, wrinkled and furrowed 
by time...He always hoped to find in the faces of those who posed for him a fresh insight into the human condition, for the important thing as far as Rembrandt was concerned was not beauty but truth". (4) Thus, Rembrandt opted for "a realistic characterization of old age in his portraiture". Indeed, this was the artist's preference not just in his portraiture of other elderly models, a fashionable practice during his time, but, above all, in his portrayal of his own aging face. These realistic details are enumerated by the poet in her references to the artist's filling pouches, uglier skin and bloated nose. Thus, instead of the earlier selfportraits, which were vibrant and pompous, the poet praises the painter for his daring realism and acknowledgment of the passage of time as "all the darknesses are dared. You chose/ What each must reckon with".

Praising the artist whose "humility" is "at one with craft", Jennings marvels at the lack of arrogance as "Pride is apart/From this selfscrutiny" and, at the same time, the artist has not lost one bit of his genius, "You make light drift/ The way you want". Never ceasing to produce great art till the very end, in his paintings, "To the last/ Experiment went on".

Though Rembrandt's prolific genius never seems to decline, in a poem which certainly reveals moments of desperate uncertainty, Jennings wonders how fellow artists can cope with such bouts of lack of inspiration. In Questions to Other Artists, she asks three rhetorical questions:

Tell me, composer, tell me,

When silence comes to you,

The dance of the notes has vanished,

The wave has ceased to flow,

Tell me, painter, if there

Is a confusion of

Colours on your palette 
Which your brush can't move

Often? Does a canvas

Stare like a flouting love?

When a movement falters,

When the brushes start

Shaking to a pause,

Do you wonder what

Keeps us hunted, hunting

In the luck of art?

(The Complete Works 886)

In this poem, a significant metaphor is certainly that of the poet/artist/musician as both a hunter of inspiration and a victimized, utterly helpless prey.

Moreover, another cause for the profound respect Jennings feels for Rembrandt is his ability to stand tall despite all his misfortunes, to overcome his fear of death, and help others, especially the poet, to confront it, "Self-portraits understand,/And old age can divest,/ With truthful changes, us of fear of death." In the statement, "Self-portraits understand", lies a key-concept that a self-portrait could act as an artist's diary or autobiography. In this context, T.J. Clark's claim that "among all artists, Rembrandt is the only one who has turned self-portraiture into an autobiography" is quoted by Marcus and Clarfield. (2) Besides, Lisa Marder rightly regards Rembrandt's self-portraits as a visual diary that shifts from a questioning young artist, through the confidence of middleage success, to the more contemplative, revealing portraits of older age produced in the 1650 s and 1660 s.

As Jennings confesses in her ekphrastic poem, she seems to envy the bravery, honesty and skill of the artist's brush: "You stare/ Into yourself, beyond. Your brush's care/ Runs with self-knowledge. Here/ Is humility 
at one with craft". In fact, Jennings' observation of the artist brings them close in a process of near-identification where she places herself in his dignified stature. In this context, Derrida's statement mentioned by Bilman that in ekphrasis the poet's signature is added to the painter's, is quite relevant. Derrida holds that the ekphrastic poet expands the significance of the artwork according to his/ her own subjectivity, thus creating a "surplus" to the painting. It is as if the poet's signature supplements the painter's signature. Thus, the double signatures of the painter and the poet "create the ekphrastic work's identity, and transcend it by adding the poet's and the painter's signatures to its presence, thus augmenting the reader-perceiver's aesthetic appreciation". (11) Besides, an ekphrastic poem like Elizabeth Jennings' Rembrandt's Late SelfPortraits is like "the reflection of natural forms on a river, oscillated by a breeze, whose study explores the ekphrastic relation as a dynamic and evolving process between the poet, the painter, and the reader-perceiver". (12) Indeed, by staring not just into himself but also beyond, Rembrandt's late self-portraits speak not only to Jennings, but to humanity at large. Referring to the universality and relevance of these self-portraits, Marder rightly believes that they prove that "what is most personal is most universal' for they continue to speak powerfully to viewers across time and space, inviting us not only to look closely at his self-portraits, but at ourselves as well". In his article on Rembrandt's last portrait in The Guardian (2004), Jonathan Jones states that Rembrandt succeeded in making the portrait "philosophical":

None of his portraits is an observed document of a person's appearance. Each is a questioning of what it is to exist. Each tries to get at the invisible mind, soul, character - whatever you call the inner person, Rembrandt paints it. His paintings are not concerned with visual pleasure for its own sake, but only in so far as it leads to knowledge".

Thus, the philosophical task of striving to know oneself, in keeping with the doctrine of 'know thyself,' is evident in Rembrandt's self-portraits. One cannot help agreeing with Lackey that such paintings as the artist's late self-portraits constitute an effort at self-understanding that few philosophers have achieved". (2) 
And this is precisely what Jennings admires in his last self-portrait; the attempt to achieve self-knowledge. Further emphasizing the relevance of self-portraiture, Jones asserts that portraying his ever-changing self, provided the artist with an extremely rich subject in his journey of selfdiscovery. So great was the artist's obsession with self-observation that Nina Siegal calls Rembrandt in her New York Times article (2015) "arguably the original master of the selfie" as well as "a master portrait painter" whose self-portraits create "an autobiography in pictures, revealing the physical and emotional changes of the artist as he ages...As he gets older, this essential Rembrandt comes out of fancy dress, drops the masks and fantasies, and looks himself and us in the eye with a directness that is unparalleled in art". Analyzing the elements of the last self-portrait as reflecting the artist's emotional and philosophical stance, Jones describes it as a "valedictory painting":

Rembrandt finds himself intensely moving as a subject. The rich subdued glow of the picture, the light filling his wonderful face, the subtle magnificence of his clothes, the dignity of his pose with his hands clasped and his head turned patiently towards us as if bearing immense pain with tragic endurance: this painting would communicate agony and acceptance even if we knew nothing about Rembrandt's life, the spectacular success followed by bankruptcy and, by this time, the deaths of almost everyone he loved.

Indeed, it is this striking similarity between the artist's dignified, valedictory painting and Jennings' attempt to maintain her dignity and overcome her fear of failure and death that brings about this admirable though imaginary artistic dialogue between Jennings and Rembrandt through ekphrasis.

In a poem entitled Old Woman (1958), Jennings tries to come to terms with her own loneliness and despair:

arranging flowers in a vase,

as she is alone and they

are all she's got and they're

obedient: 
The old woman tries to attain self- acceptance:

Drawing the curtains back and opening windows

Every morning now, she feels her years

Grow less and less. Time puts no burden on

Her now she does not need to measure it.

It is acceptance she arranges.

And her own life she places in the vase.

(The Complete Works 166)

Perhaps Rembrandt's acceptance of his old age is what Jennings really envies. Moreover, she could be envious of his art which makes him do away with words; the tools she often feels incapable of mastering. In Stanza 2 of her poem entitled Old Man, Jennings offers a description which could apply to Rembrandt:

\section{What}

His life has made of him his shadow shows -

Fine graces gone but dignity remaining

While all he shuffled after is composed

Into a curve of dark, of silences:

An old man tranquil in his silences.

(The Collected Poems 168)

On the other hand, several of Jennings' ekphrastic poems about art and artists raise the question whether painting is more apt than words. While the viewers of art keep hovering round the painted model in all directions, the poet trying to interpret the painting, time seems to stop majestically for the painting that is unaware of the sense of awe and mystery it has aroused in its viewer or interpreter:

And we move round him, are his own world turning, 
Spinning it seems to him, leaving no shadow

To blaze our trail. We are our actions only:

He is himself, abundant and assured,

All action thrown away,

And time is slowing where his shadow stands.

It appears that the poet finds in the experience of viewing a painting a refuge from her own confusion, being at a loss for words. In Visit to an Artist (1961), she seems to think that painting is more straightforward, more honest and more apt than mere words:

And every shyness that we brought with us

Was drawn into the pictures on the walls.

It was so good to sit quite still and lose

Necessity of discourse, words to choose

And wonder which were honest and which false.

It thus becomes evident that Jennings projects her own disillusionment and fears unto Rembrandt's self-portrait in such a way as to affirm Hubert Damisch's statement summarized by Bilman as follows: "Through a different sign system, a poet is able to transcribe accurately the forms of painting into a poetical text; but the result is likely to exceed the painting's meaning, due to the connotative implications of poetic words". (47) Thus, an ekphrastic poem may be said to add a human dimension to the painting it portrays. Besides, as Bilman notes, it adds verisimilitude to it and creates a kind of "interaction of art and reality and the viewerreader's relation to reality so that ekphrastic relation involves a social reaction". (48) Moreover, there is an important psychoanalytic perspective as the ekphrastic poem "represents the poet's own body that voyeur-readers actively look into while reading". (154) Hence, by contemplating Rembrandt's situation, Jennings seems to lay bare her own emotions, above all fear, and doubt. In Michael Hamburger's view, "The [ekphrastic] poems are not literal descriptions of the paintings, but rather, 
through the impact that the painting makes on the poet, show how the effects of the painting can be transcribed into the poetic text". The visual impact of the painting is therefore based on "the poet's projection and his idiosyncratic sensibility". (161) In this context, it is relevant to mention Grant F. Scott's statement:

As a genre, ekphrasis has everything to do with the shape of the poetic work: it explores the iconicity of words, sentences and stanzas, and continually entertains the word's ambition to replicate the immediate visual beauty and stillness of the artwork. Nevertheless, ekphrasis is never just about technical problems - the syntactic and semiotic paradoxes that bedevil interart description but it is as much a psychological and cultural as a literary topos, reflecting the anxieties of the perceiving eye, the agon or rivalry that emerges between the sister arts, and the persistently (though not exclusively) masculine project of surveying and attempting to control the feminized artwork . (3)

However, in the case of Jennings' ekphrastic poem one hardly senses any rivalry, but rather, empathy, admiration and a sense of insufficiency when confronted with the work of such a genius as Rembrandt. Elizabeth Jennings praises the artist's ability to transform sorrow into art, as creativity becomes a sort of cure. In Marcus and Clarfield's words, referring to Neiderland (1989) and Pollack (1980), creativity could be regarded as "a compensatory response to mourning and loss", (6) serving as "a restitutive function of the ego". Significantly, they refer to Covey (1991) who holds that Rembrandt's self-portraits shift from the optimism of youth to the serenity of old age, especially in Rembrandt's last selfportrait of 1669 in which his watery eyes indicate personal tragedy. However, they quote Stein's relevant statement that in this painting he certainly emerges triumphantly as "the fully realized man of power and authority". (qtd. 8) In addition, Marcus and Clarfield refer to the view held by several critics such as Somonton (1990), Kastenbaum (1992) and others who marvel at "the outstanding creative achievements of many artists in their last years of life (such as Rembrandt, Titian, and Monet) and the development of a distinct 'old age style' [which] supports the notion that artistic ability ... can be preserved and even enhanced in the elderly". (9) 
Though some critics may emphasize Rembrandt's portrayed physical decline as denoting sadness and discomfort, others, like Chapman see "no misery, senility or mental decline". Instead, Rembrandt's late paintings "mask his cares in order to voice his self-esteem". (qtd. 11)

Finally, Elizabeth Jennings' ekphrastic poem about Rembrandt's late self-portraits is a wonderful synthesis between poetry and art. It does not merely reveal her reverence and empathy for the great artist whose life was marked by rollercoasters of success and tragedy, but, more importantly, her own self-pity. Indeed, in her quest for self-consolation and reassurance, the troubled poet projects her own loneliness, doubts and suffering onto the painting in such a way as almost to exceed it. Thus, in Derrida's words, the poet masterfully adds her own "signature" to Rembrandt's great self-portrait through her verbal representation. Crossing the boundaries of time and culture, Jennings' ekphrastic, contemplative poem is thus a delving into the universal issues of selfknowledge, dignity, and creativity despite old age. It is as though the selfportrait allows the poet and the reader to stare into themselves. Moreover, by musing over Rembrandt's powerful and dignified self-portrait, Elizabeth Jennings helps "divest" us of our own fear of old age, decline and death. 


\section{Works Cited}

Belsey, Catherine. "Invocation of the Visual Image, Ekphrasis in Lucrece and Beyond,"

Shakespeare Quarterly, Volume 63, Number 2, Summer 2012.

https://doi.org/10.1353/shq.2012.0029

Accessed 9/11/2018

Bilman, Emily. Modern Ekphrasis. Peter Lang AG, Internationaler $\underline{\text { Verlag der }}$

Wissenschaften. Pdf, Switzerland, 2013

http://dnb.d-nb.de

Accessed 30/7/18

Gardner, Timothy. "Learning the Lesson of Love: The Poetry of Elizabeth Jennings (1926-

2001). New Blackfriars, Volume 83, Issue 979, 09/2002.

www.jstor.org/stable/43250193

Accessed 5/8/2018

Gioia, Dana. "Clarify me, please, God of the Galaxies: Dana Gioia praises the poetry of

Elizabeth Jennings". First Things: A Monthly Journal of Religion and Public Life, Issue 283,

$05 / 2018$

www.firstthings.com/article/2018/05/clarify-me...

Accessed 7/8/2018

Hodge, Susie. Art. London and China: Quercus Editions Ltd, 2013.

Jennings, Elizabeth. The Collected Poems. Edited by Emma Mason Carcanet, 2012. 
www.gurbaksishgroup.com/pdf/the-collected-poems

Accessed 14/5/2018

Jones, Jonathan. "Portrait of the Week: Self-Portrait at the Age of 63, Rembrandt (1669)",

The Guardian, Saturday 28 February, 2004.

https://www.theguardian.com/culture/2004/feb/28/art

Accessed 28/6/2018

Lackey, Douglas P. "Rembrandt and the Mythology of the Self-Portrait," The Philosophical

Forum, Volume 37, Issue 4, 2006.

www.philpapers.org/s/Douglas Lackey

Accessed 11/9/2018

Lindop, Grevel. "Elizabeth Jennings Obituary", The Guardian, 31 October, 2001.

https://www.theguardian.com/news/2001/oct/31/guardian...

Accessed 5/8/2018

Marder, Lisa. "Rembrandt's Self-Portraits and His Aging Process", Updated Nov. 20, 2017.

WwW.thoughtco.com/rembrandts-selfportraits-4153454

Accessed 2/8/2018

Marcus, Esther-Lee and Clarfield, A. Mark. "Rembrandt's Late SelfPortraits: Psychological and

Medical Aspects". The International Journal of Aging and Human

Development, Vol. 55 ,

Issue 1.

www.journals.sagepub.com/doi/pdf/10.2190/8LQ5-CC7W-UJDF-

$\underline{\mathrm{TNMO}}$ 
الجزء الثاني

\section{Accessed 9/11/2018}

Rembrandt, Harmenszoon van Rijn. Last Self Portrait, 1669.

www.nationalgallery.org.uk/paintings/rembrandt-self-portrait-at-the$\underline{\text { age-of-63 }}$

\section{Accessed 2/5/2018}

Scott, Grant F. "Copied with a difference: Ekphrasis in William Carlos Williams' Pictures

from Brueghel”. Word \& Image, 15:1.

http://www.tanfonline.com/loi/twim20

Accessed 9/11/2018

Siegal, Nina. "With Rembrandt, the Selfie Takes on New Meaning". The New York Times, April

$16,2015$.

www.nytimes.com/2016

Accessed 31/7/2018

الكلمات الرئيسية: إكفراسيس - إليزابث جنتجز - شعر - رمبرانت ـ البورتريه الذاتي 